11h30 - 13h | Aug. 23, 2017-Wednesday | ROOM 12

\title{
TECHNOLOGY AND BUSINESS
}

\section{SUBSCRIBER TV / VOD AND OTT}

\section{Chair: Mauricio Donato - Editorial Advisor - Revista da SET}

The emergence of the mass media, radio, television and the internet have caused significant changes in the most different narratives. And as technologies get better, new players are being added. In this context, the perspectives of convergence of the media in the Brazilian audiovisual market are overwhelming, considering the dizzying changes in the behavior of the viewers when watching audiovisual content. Whether via open TV, subscription, OTT and Vod. The Tv subscription panel versus OTT \& Vod has the proposition of discussing in depth this convergence present in the digital era and in the lives of producers, engineers and consumers of the audiovisual market.

- Speaker: Marcelo Coutinho - Professional Management Master's course coordinator EAESP-FGV

- Speaker: Oscar Vicente Simões de Oliveira - Executive President of ABTA Brazilian Association of Pay TV

- TV EVERYWHERE

\section{Speaker: Guilherme Saraiva - Technology Director of Telecine}

Telecine Play: no mundo da informação e entretenimento ágil.

O Telecine criou uma nova plataforma tecnológica para os seus assinantes. Através do site e dos aplicativos do Telecine Play o assinante terá o serviço conhecido como TV Everywhere. Nesse painel desvelaremos qual tecnologia está a disposição do Telecine Play e em função dessa nova plataforma de mídia quais melhorias podemos trazer para a nossa audiência.

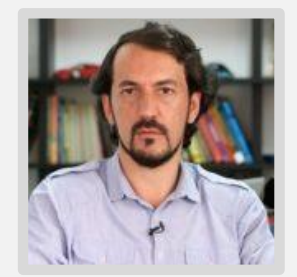

Mauricio Donato - Editorial Advisor - Revista da SET

Mauricio Donato holds a degree in Radio and TV from the Methodist University of São Paulo; Master's degree in Communication in the Contemporaneity by the Cásper Líbero Faculty and doctorate by USP / ECA, developing the thesis "Applicability of new technologies in the era of digital TV in 4k and 8k". She has extensive experience in the direction of television programs, developing projects on TV Globo, SBT, and on TV Record Network. He had an active participation in the SBTVD (Brazilian Digital TV System) Forum. He is currently a professor at Universidade 
Anhembi Morumbi, teaching the discipline Direction in TV and Audiovisual Media and in FAPCOM directing the disciplines of audiovisual planning and broadcasting technology.

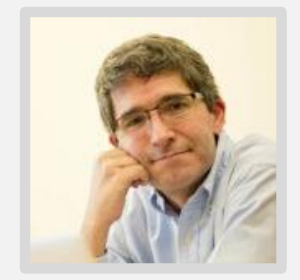

\section{Marcelo Coutinho - Professional Management Master's course coordinator EAESP-FGV}

Columnist of Meio \& Mensagem and member of the Technical Committee of Media of CENP. He was Global Director of Intelligence at Terra-Telefonica, Executive Director of IBOPE Intelligence, Director of Analysis Services for Latin America at IBOPE / NetRatings, Visiting Researcher at Harvard International Technology Group, Marketing Manager and Assistant Editor of International Economics In the State Agency. He is the author of the first works in Brazil on the use of social networks and programmatic media in market research, in addition to the chapters on Brazil in the first editions of the Global Information Technology Report published by the World Economic Forum. $\mathrm{He}$ has held dozens of lectures, including the Cannes Advertising Festival, the American Association of Advertising Agencies and the World Association for Public Opinion Research among others.

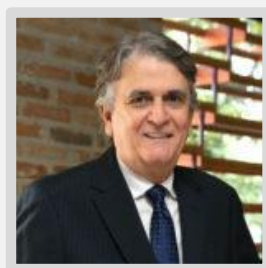

\section{Oscar Vicente Simões de Oliveira - Executive President of ABTA - Brazilian Association of} Pay TV

Currently, he is the Executive President of ABTA - Brazilian Association of Pay TV, where he is responsible for the management of the entity, and for the representation of the associates, aiming at the defense and development of this economic sector, especially at the regulators of its activities. He was the President of the National Union of Signature Television Operators and Conditioned Access Service (SETA) from 2013 to July 2016. He is a member of the Advisory Board of C + Tecnologia and associated to IBGC - Brazilian Institute of Corporate Governance and FFI- Family Firm Institute and member of the Advisory Board of several national companies. He holds a Masters degree in Business Administration from the Pontifical Catholic University of São Paulo and a Specialization in Advanced Management from INSEAD - The European Institute of Business Administration and Fundação Dom Cabral, among others.

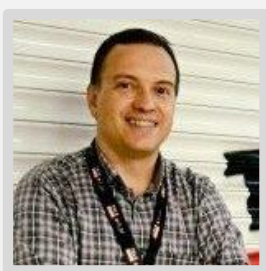

\section{Guilherme Saraiva - Technology Director of Telecine}

Guilherme is Telecine's Technology Director. Graduated in Telecommunications Engineering from the IME, with an MBA in Marketing and a Master in Finance from FGV, he led Globosat's technology planning area and worked at NET's corporate clients unit at the launch of Vírtua. He coordinated the planning of the expansion of the British Telecom operation in Latin America, where he participated in digital inclusion projects in several countries.

Cite this article:

Donato,M., Coutinho, M., de Oliveira, O. V. S. and Saraiva, G.; 2017. Subscriber TV / VoD and OTT. ISSN Print: 2447-0481. ISSN

Online: 2447-049X. v.3. doi: 10.18580/setep.2017.29. Web Link: http://dx.doi.org/10.18580/setep.2017.29 